argues strongly for a low threshold for diagnostic lumbar puncture in such cases.

1 Bayer AS, Seidel JS, Yoshikawa TT, Anthony BF, Guze LB. Group D Enterococcal meningitis: Clinical and therapeutic considerations with report of three cases and review of the literature. Arch Intern Med 1976;136: review
2 Musher DM. Enterococcus species and group D streptococci. In Mandell GL, Douglas-RG, Bennett JE, eds. Principles and Practice of infectious diseases. New York: Churchill Livingstone, 1990:1550-4.

3 Klein JO, Marcy SM. Bacterial sepsis and meningitis. In: Remington JS, Klein JD, eds. Infectious diseases of the fetus and new born infant. Philadelphia: WB Saunders, 1983:679-734.

\title{
Haemorrhagic colitis and haemolytic-uraemic syndrome: False positive reaction with a rotavirus latex agglutination test
}

\author{
R P Bendall, J J Gray
}

\begin{abstract}
A stool sample from a child with haemorrhagic colitis and haemolyticuraemic syndrome gave a positive reaction with the RotaScreen latex agglutination test in the absence of other evidence of rotavirus infection. When this test is performed on bloody specimens, positive reactions should be interpreted with caution and confirmed by other means.
\end{abstract}

Haemorrhagic colitis can be caused by an infection with verotoxin producing strains of Escherichia coli $0157 .{ }^{1}$ This in turn has been associated with the haemolytic-uraemic syndrome $^{2}$ which is an uncommon condition, principally of children, and associated with significant morbidity and mortality. ${ }^{3}$ By contrast, rotavirus infection is a common, selflimiting condition and does not usually cause any long term sequelae. ${ }^{4}$ We describe a patient with haemorrhagic colitis and haemolyticuraemic syndrome whose stool gave a false positive reaction in a latex agglutination test for detecting rotavirus.

A 4 year old girl was admitted to this hospital with a three day history of diarrhoea, becoming bloody on the day of admission. She was vomiting but not clinically dehydrated.

Results of rotavirus antigen detection and electron microscopy

\begin{tabular}{|c|c|c|c|c|}
\hline \multirow{2}{*}{$\begin{array}{l}\text { Day faecal } \\
\text { sample taken }\end{array}$} & \multicolumn{2}{|c|}{ Latex agglutination } & \multirow{2}{*}{$\begin{array}{l}\text { Rotavirus antigen } \\
\text { ELISA }\end{array}$} & \multirow{2}{*}{$\begin{array}{l}\text { Electron } \\
\text { microscopy }\end{array}$} \\
\hline & Test & Control & & \\
\hline $\begin{array}{l}1 \\
3 \\
5\end{array}$ & $\begin{array}{l}++ \\
+ \\
-\end{array}$ & $\begin{array}{l}- \\
- \\
-\end{array}$ & $\begin{array}{l}\text { Negative } \\
\text { Negative } \\
\text { Negative }\end{array}$ & $\begin{array}{l}\text { No virus seen } \\
\text { No virus seen } \\
\text { No virus seen }\end{array}$ \\
\hline
\end{tabular}

She had an oral temperature of $37 \cdot 3^{\circ} \mathrm{C}$. Physical examination was normal and her white cell count was raised at $18.5 \times 10^{9} / 1$ with normal haemaglobin at $145 \mathrm{~g} / \mathrm{l}$ and a platelet count of $404 \times 10^{9} / 1$. Urea and electrolytes were all within normal limits (sodium $136 \mathrm{mmol} / \mathrm{l}$, potassium $4.0 \mathrm{mmol} / 1$, urea $3.2 \mathrm{mmol} / 1$ and creatinine $62 \mu \mathrm{mol} / \mathrm{l})$.

A faecal sample was sent for bacteriological and virological examination; it was bloody and liquid. The RotaScreen latex agglutination test (Mercia Diagnostics Ltd, Surrey) for detecting rotavirus antigen was performed according to the manufacturer's instructions on a centrifuged extract of this sample. It agglutinated the latex particles coated with rabbit anti-rotavirus antibody (test latex), but not the latex particles coated with normal rabbit globulin (control latex); this was interpreted as evidence of rotavirus infection.

By the third day after admission the patient had become oliguric with peripheral oedema noted on examination. The haemaglobin had fallen to $101 \mathrm{~g} / \mathrm{l}$, there was thrombocytopenia (platelet count of $54 \times 10^{9} / 1$ ) and a white cell count of $11.6 \times 10^{9} / 1$. The blood film contained numerous red cell fragments, spherocytes and burr cells. There was evidence of renal impairment with urea at $15 \mathrm{mmol} / 1$ and creatinine at $279 \mu \mathrm{mol} / 1$. Haemorrhagic colitis and haemolytic-uraemic syndrome were diagnosed.

The next day an organism, subsequently identified as a verotoxin producing strain of $E$ coli serotype 0157 , was isolated from the stool. No other enteric pathogens were isolated. Her renal function deteriorated further and she required peritoneal dialysis for 12 days.

Stool samples from days 1, 3, and 5 were retested with the RotaScreen test, examined by electron microscopy, and tested with a 
rotavirus antigen ELISA (Rotaclone, NovoNordisk, Cambridge) (table). These results suggest that the positive reactions with the latex test were not specific for rotavirus antigen.

Latex agglutination tests are generally accepted as having a specificity approaching that of electron microscopy in the diagnosis of rotavirus infection. ${ }^{56}$ Laboratories that lack the facilities for electron microscopy can rely on this method as the sole test for making the diagnosis of rotavirus infection. A test which confuses haemorrhagic colitis with rotavirus infection could be falsely reassuring to the clinicians caring for the patient, especially when the result is available a day or two before the results of bacteriological investigations. In the light of our results we recommend that positive results with the RotaScreen latex test be confirmed by some other means.
We are currently looking at faecal samples collected from other patients with bloody diarrhoea to ascertain the incidence and nature of false positive reactions with this test.

1 Symonds J. Haemorrhagic colitis and Escherichia coli 0157-a pathogen unmasked. Br Med J 1988;296:875-6.

2 Karmali MA, Petric M, Lim C, et al. The association between idiopathic hemolytic uremic syndrome and infection by verotoxin-producing Escherichia coli. J Infect Dis tion by verotoxin-

3 Kaplan BS, Thompson PD, de Chadarevian J-P. The hemolytic uremic syndrome. Pediatr Clin North Am 1976;23:761-77.

4 WHO Scientific Working Group. Rotavirus and other viral diarrhoeas. Bull WHO 1980;58:183-98.

5 Sanekata T, Yoshida Y, Okada H. Detection of rotavirus in faeces by latex agglutination. J Immunol Methods 1981; 41:377-85.

6 Haikala OJ, Kokkonen JO, Leinonen MK, et al. Rapid detection of rotavirus in stool by latex agglutination: comparison with radioimmunoassay and electron microscopy and clinical evaluation of the test. J Med Virol copy and clinica

\title{
Detection of Borrelia burgdorferi in patients with Lyme disease by the polymerase chain reaction
}

\author{
E C Guy, G Stanek
}

\begin{abstract}
Borrelia burgdorferi, the causative agent of Lyme disease, was detected in patients' serum by DNA amplification using the polymerase chain reaction (PCR). B burgdorferi was pelleted from serum samples by centrifugation $(10000 \times g$ for 10 minutes) and lysed by treatment with ammonium hydroxide $\left(100^{\circ} \mathrm{C}\right.$ for 15 minutes). Two pairs of "nested" PCR primers complementary to the gene encoding a major outer surface protein (OSP A) of B burgdorferi were used in DNA amplification under standard PCR conditions (Perkin-Elmer Cetus). Two out of five patients with erythema migrans, the characteristic primary skin lesion associated with early Lyme disease, were positive by the PCR. This method could form the basis of a useful routine laboratory test in those cases of early Lyme disease where conventional serological testing commonly yields equivocal or false negative results.
\end{abstract}

The early diagnosis and treatment of Lyme disease can prevent progression to the later, more serious neurological and arthritic com- plications.' Unfortunately, the serodiagnosis of early Lyme disease is difficult due to the absence or barely detectable antibody response in the first weeks of infection. Furthermore, isolation of Borrelia burgdorferi, the causative agent of Lyme disease, from specimens is notoriously slow and difficult. ${ }^{2}$ We report a method, based on the polymerase chain reaction (PCR), for the direct detection of $B$ burgdorferi in the serum of patients manifesting the primary skin lesion of Lyme disease, erythema migrans.

\section{Methods}

Two pairs of "nested" PCR primers were constructed complementary to the gene encoding the $O s p-A$ protein of $B$ burgdorferi strain B31. ${ }^{3}$ Primer pair $1, O s p A-N 1$ (5'GAGCTTAAAGGAACTTCTGATAA-3') $O s p A-C 1$ (5'-GTATTGTTGTACTGTAATTGT-3'), and primer pair 2, OspA-N2 (5'ATGGATCTGGAGTACTTGAA-3') Osp $A$ C2 (5'-CTTAAAGTAACAGTTCCTTCT3'), correspond to nucleotide nos 334-356, 874-894, 362-381 and 693-713, respectively, of the $O s p A$ gene. The primers chosen are complementary to regions of the gene that are highly conserved between strains B31, ACA1, 